\title{
SOCIAL POLICY AS FACTOR OF STATE INSTITUTIONAL STATUS
}

\author{
Larysa ZHUKOVA ${ }^{1}$, \\ V.N. Karazin Kharkiv National University, Ukraine
}

\begin{abstract}
The purpose of the article is the research of theoretical and methodological aspects of social policy as the factor of institutional state statuses. Methodology. The researching in institutional providing of state social policy which may be considered as the base for performance of correspond reforms which are directed to the life level increasing, is enough popular task in scientific, theoretical and practical aspects. The scientific search of social policy as the factor of institutional status of state is carried out at the base of classical, neoclassical and institutional methodology. At the base of classical methodology it were defined the general approaches with help of dialectical analysis tools and synthesis of social relations array as historical action. With the help of system, structurally-functional analysis of social policy tasks, it's opened its internal nature and ways of institutional providing. Institutional and neoclassical approaches allowed the specials analysing tools in modelling of dynamics and institute of social policy institute results in the conditions of market transformations. Also in the research process it were used the economic articles about the question of analysis in state social policy and given the statistic data about the analytical report to the annual President's of Ukraine message to Verkhovna Rada of Ukraine „About internal and external condition of Ukraine in year 2015". Research results showed what in the conditions of socially-economic and political instability, the social sphere Ukraine became the hostage of common crisis in economic, catastrophic decreasing of life level, increasing of social confrontation and rough system mistakes in the process of social institution formation. All of this neutralizes the methods efficiency about improvement of socially-economic condition of population and prevents to the implementation of necessary reforms. Practical value lays in the clear definition of priorities and directions of social policy at the state level, outlining of the main efficient ways and forms for citizens problems solving, coordinating of different social institutions activity, considering of socially-economic state development features and appearing of conditions for life level increasing. By the striving for integration to European space and building of own development strategy has to clearly understand own possibilities and external factors of influence. By the choosing the possible alternatives, the main idea of social policy should stay the strive for social justice of society and providing of stable market which doesn't make worse the conditions and possibilities of future generations. Value/originality in the research process it's proves that one of the primary task must be magnificent change of social policy vector and performance of urgent economic and social reforms. Looking to this, social policy institute needs serious modernization, especially in its functional displays which could be more directed to the for state social development closing for European standards. Closing of Ukraine to the economic and social standards of developed countries needs the building of socially justice society, providing of suite life conditions for socially vulnerable levels of population and increasing in efficiency of human rights protection system. In this direction, the government has to decrease the social expenses to the budget by means of private investments, transmission targeted support needy. In conditions of budget means economy, it should be carried out the transmission from paternalism in the social sphere to partnership between state, business and citizens in all aspects of social support, the result of successful functioning of social policy functioning as factor of institutional state status must be general development of Ukrainians life level.
\end{abstract}

Key words: state, social institute, social policy, institutional state status, institutional changes, social reforms.

JEL Classification: A14, E02, 1138

\footnotetext{
Corresponding author:

${ }^{1}$ Department of Finances and Credit, V.N. Karazin Kharkiv National University.

E-mail: lnzhukova@mail.ru
} 


\section{Introduction}

Deep social, political, economic and, as the result, ethically-psychological problems appear in the conditions of social economic formation, in every society. It causes the normal life infraction of the society majority, escalation the personal and social groups problematic and also the inability to independently solve some socializing tasks. As the result of this is the social deformation, values demolition, development of destabilizing processes development in all spheres of social life.

At the modern stage of Ukrainian development, as the result of certain objective and subjective consequences, it's still didn't form the civil democratic society. State must be responsible for citizen's welfare as the social institute of social life organization. State must be a warrant of citizen's assurance into the satisfaction in needs of social organization, provide the stability of communications and relations within this organization. In its turn, social state which functions as the macro-level social institute, forms its own structure and organizes the life-sustaining of all social spheres funding on the constitutional bases. Notion „social” foresees that state will performance the social policy which is directed on the providing of needs and interests of all social classes, lawyers, separate groups and social members (Kryvokon', 2012).

It's a pity that today the transformational processes in our country are accompanied with negative results in all spheres of social life - politic, economic, social, etc. All of this causes the appearing of socially-politic contradictions, increasing of conflict level, growth of social constraint, distrust population to government. The main criterion for majority of citizen's success is its ability to regulation problem which appears (Lopushniak, 2011). That's why the research of institutional providing in state social policy which may be considered as the base for correspond reforms performance which are directed to the increasing of life level which is enough actual task as in theoreticallyscientific as in practical aspect.

The purpose of article is the research of theoretical and methodological aspects of social policy as the aspect of institutional state status.

The scientific search of social policy as the aspect of institutional state status which is carried out at the base of classical, neoclassical and institutional methodology, At the basis of classical methodology it were defined the general theoretical approaches with the help of instruments dialect analysis and synthesis of social relations array as the historical action. With the help of structural and functional analysis in social policy tasks it's opened the internal nature and ways of institutional providing of social policy. Institutional and neoclassical approaches allowed analysing the specific modelling instruments and results of social policy institute in the condition of closing of Ukraine to economic and social standards of developed countries.

\section{Institutional approach to the analysis of social state policy}

Usage of constitutional theories for analyses of social problematic has its own history and repeated appealing to them by the most famous scientists include Nobel laureates testifies about their scientific attraction. The works of H. Spenser and E. Durkheim became the theoretical basis of institutional approach to the analysis of state social policy as the social institute. In their interpretations, social institutes got the meaning key notions which explain the laws of social development at the basis of comparative and historical approach (Voytovych, 1998). The institutional approach got the powerful development into the researches of modern theory of market balance and welfare creators L. Hicks and K. Arrow (1972). Socially-institutional direction as independent direction was outlined in the neoconstitutionalism by Nobel laureates D. Buchanan (1986) and R. Coase (1991) with the using of economic methods in researching of ecologic, politologic and sociologic processes. In 1992 G. Becker got the Nobel Prize for development of statements about connection between human behaviour and their interaction.

Let's note that questions of theoretical and methodological aspects of institutional regimentation of approaches about state social policy paid attention to the domestic and foreign scientist such as: T. Veblen (research of society evolution as process in natural selection of social institutes), V. Geyets (institutional and structural transformations of national economy in the context of effective model creation in state social policy), A. Grytsenko (institutional very tectonics and alternatives of the institutional choice), A. Inshakov (research of economic systems of development), A. Kolot (institutional changes and justification of conceptual bases of the choice of model in global economic development), L. Lysiak (social and economic development of the state in the context of modernization of national economy), D. Nort (a role of economic institutes in selection and realization of alternatives of the state social policy), V. Sadovaya (research of regional social policy in Ukraine), V. Savka (institutional ensuring development of social work in Ukraine, in particular reforming of the social sphere), J. Hodgson (the concept of formation and development of social and economic institutes), A. Chukhno (transformation of economic systems in a section to questions of effective ways choice in institutional state policy development in the social and economic sphere), etc. But the questions which are connected with creation of the social policy institute in the context of economic development alternativeness are still insufficiently researched.

\section{Research of category „social policy” notion}

In connection with reformation of economic relations in the state, the implementation of market relations got the problem of social relation regulation which is solved in a way of correspond policy realization. That's why the 
social policy today is one of the most important directions in internal policy.

The general analysis of social policy testifies that essential problems appear in this sphere are born by the social uncertainty in the system of social institutes and needed the research in the context of constitutional changes in state administration.

The polyaspectness of politic actions generally explains the fact of absence in one social policy definition. In spite of fact that definition of notion "social policy” is not given by philosophy, politological, sociological dictionaries, the especial attention to the theoretical and practical problems in social regulation, social sphere, social relations gives the possibility to generalize the question about essential definition social policy. In particular the reference book about social work (Andrushchenko, Astakhova, Lukashevych, 2001) contains such interpretation of given category: „Social policy - is the state activity and its institutes, agencies of local administration, domestic, foreign enterprises, institutions of all types of property, their communities and associations, domestic, foreign and foreign public and private funds, the public and religious organizations, citizens on development and management of the social sphere of society". Others authors (Shevchuk, 2003) gives the follow definitions: „Social policy - is a system of programs, services and events are directed to the social purposes achievement. Social policy covers all spheres of human life activity such as - industrial, social, political, spiritual and regulates the relationship between the community group, community, entity in each of these areas and areas of interaction." As it's seen from above said extracts, the main purpose of social policy is the creation of conditions for social needs and human interest's satisfaction and also for support, protection and rehabilitation of separate citizens and social groups.

One more important aspect of given category is discovered in notion which is offered by V.A. Skuratskyi and O.M. Paliy (Skuratskyi, Paliy, 2002). They define the social policy as "social phenomenon combines the polyfactual elements: constitutionally-legal, institutional, administrative regulatory and self-regulatory, global, national, state, supra, social, humanistic, praxeological (value), communication and so on".

Researching the essence of social policy, specialists give it the space for social relations between state, market and citizens, space for relations functioning, executed as institutes and practices. Social policy institute gets the special place even among the creational social institutes. Exactly on its position in hierarchical system of such institutes we may judge about the achievements of human environment providing as the highest social value (Skuratskyi, Paliy, 2002). The alternative version lays in the fact that in spite of social polity human consideration (wide or narrow), it's focused to the human interests, its health, honour and dignity, integrity and security.

We note that in narrow understanding, social policy means the activity of its subjects by the formation of social security of person and society. In wide understanding, social policy - is the system of management, regulative, self-regulative and forms of subject's activity, array of principles, decisions which are realized in the social programs and social practice with the goal of social needs satisfaction, balance in human interests, social groups, social goals, solving social problems forming social values. By this in wide understanding, social policy-is the system of not only institutional but also the above institutional (such which are in the competence of other social institutes), state and civil, social and personal, individual ways and forms of activity which are directed on the social development, creation of conditions for polydirectional self-realization of human potential and its essential powers (Skurativskyi, Troshchynskyi, 2010).

So it's necessary to admit that the common factor lays in the fact that social policy is appealed for relations regulation in the society in the interests of social groups and connected with the list of governmental events which are directed to the increasing of population welfare.

\section{Alternatives searching of state social development}

Different states chose their own model of social policy but all of them foresee the creation of conditions for direct functioning providing of all socially-politic institutes system about regulation of social relations. The majority of scientists thinks that the object of the state social policy is the general in particular social relations, life social processes which directly or not influence to the formation of human social security, satisfaction of its personal needs and interests, studying and creation of social values.

The important tasks of state social policy in the conditions of the establishing of the market relations by the mind of P.I. Shevchuk is the gradual limitation in influences of factors which stops the social progress and the strengthening the factors of social progress, increasing $\mathrm{f}$ social and economic security of person. The features of modern social policy are its activity and efficiency (Shevchuk, 2003). All these two characteristics well demonstrate the existing in the society tendencies about possibilities of personal problems solving by the ordinary citizens. It is going about conditions creation by the state for supporting of potentially active social members in a way of encouraging their social-economic activity. In the same time, the passive social policy is based on the welfare and retention principles.

In the conditions of modern transformations in sociallypolitic regime, the clear definition in priorities and social policy directions at the state level, outlining the main efficient methods and forms of human social problems solving, activity coordination between activity of different social institutions, features consideration of social and economic state development and creation of conditions for high population life level. By the way, for successful social policy realization, it's necessary to correctly formulate the 
content of its social programs. It's referred to the necessity of system approach using by the development of and defining of social and political directions and projects.

Social policy of modern world can't be considered in the isolation from the global changes and global challenges which influence to the general social interest and allhumanity security. Global development problems which are connected with environmental deprivation deepening inequality, the persistence of significant risks of poverty and social exclusion, social and military conflicts, the spread of terrorism can't be solved without united powers of all humanity.

Ukraine has to clearly realize its own possibilities and external factors of influence by the aspiring for integration with European space and building its own development strategy. Chose of possible alternatives is too difficult task but the main idea of social policy should stays the aspiring for social justice and providing of stable development which doesn't makes worse the conditions and possibilities for future generations.

Today Ukraine is in the too difficult conditions (military actions of East, economic deprivation, social stress) which essentially complicated the possibilities of realization in social policy and form the branch of uncertainty (Makarova, 2015).

Escalation of economic and socially-politic situation in Ukraine not only moves away the domestic eurointegrational perspectives but also forms the risks which may soon cause the next social explosion and final of the national economy deprivation and loss of sovereignty. That's why one of the most important tasks is magnificent change of social policy vector and performance of urgent economic and social reforms.

Objectively chosen by Ukraine course which is oriented to the Europe and determination to defend it by population testifies about the readiness of society to make difficult and long way of reforms for reaching the high level of welfare, correspond social security, full realizing of democratic principles, human rights and freedoms. But the requirements which given by European Union and different international organizations need the performance of urgent and very unpopular methods in the field of budget and tax policy, social and retirement providing, housing and municipal management, education, medicine and also corruption liquidation and establishment of law supremacy. No doubt that they may be considered as the special challenges for our country.

In the same time, by the conditions of existing challenges, social sphere of Ukraine became the hostage of common crisis in economic, catastrophic decreasing of life level, increasing of social confrontation and rough system mistakes in the process of social institution formation. All of this neutralizes the methods efficiency about improvement of socially-economic condition of population and prevents to the implementation of necessary reforms (Krupa, Nesterovich, 2015). In connection with this, the especial actuality is got by the researches which are directed to the creation of scientific bases for development and realizing of efficient policy of social protection and population support.

\section{Reviewing methodology}

The performance of economic reforms may not be justification for poverty. Reforms may be directed first of all to volumes decreasing and poverty level of working population in a way of increasing of wages and strengthening of social support for having many children, disabled people, pensioners.

In year 2014 it was failed the try for stop the decreasing of population wages and as the result is the decreasing of real payment and volumes of social transfers. At the background of high inflation it causes the decreasing in the level of current consumption in Ukrainian population. But the worst decreasing in life level was pointed in the poorest population which use the majority of wages for food. By the period from March, 2014 to March, 2015 the food prises increased to the point of 52,7\%. According to the structure of general expenses, the part of food expenses increased $(54,4 \%$ by the data of first half 2014 against $52,7 \%$ in the same period of 2013). In such conditions the increasing of life level is connected with the ability of population level for increasing the basic state standards and guaranties. In year 2015 they stayed at the level of year 2013 (the subsistence minimum for able-bodied persons and the minimum wage amounted to $1218 \mathrm{UAH}$, the minimum pension - 949 UAH) but in the prices of April, 2015 the real volume of subsistence minimum for ablebodied persons amounted to $2317 \mathrm{UAH}$ (with the amount of personal income - $2561 \mathrm{UAH}$ ).

It's clearly that in conditions of social reforms and important expenses are connected with the state protection, the increasing of all social standards spectre is too difficult task but the correspond steps should be made by the appearing of minimal possibilities. State policy of social standards must be grounded on the objectiveness, honest diagnostic of life level condition, defining of terminal economic possibilities and orientation to the European standards, of state social development.

Another important aspect in state social policy is creation of balanced policy about housing and municipal services. During the period of 2014-2015 it's increased the gas price in the 4,5-9 times, from April, 1, 2015 the prices for heating are increased in $73 \%$, hot water - in $55-57 \%$. The rapid price increasing in housing and municipal services is realized by citizens as one of the worst social problems. In such conditions the unrest causes the accumulation of debt population to pay housing and utility services consumed (during 2014 it increased to 2.736 billion UAH (22.9\%) and as of February, 1.2015 was 13.045 billion UAH) (Analytical Report, 2015). In addition, the publicized by government system of compensational subsiding causes a lot of questions about the mechanisms of its realization and economic bases needs the large state expenses and may 
fully neutralize the results of tariff increasing. In addition the implementation of the subsiding system may cause the follow "shadowing" of salaries, fraud, corruption and considerable additional expenses on their administration BY the way the offered subsiding mechanism will not encourage households to economical use of resources, but also will encourage the economic position of energy companies monopoly, which may further increase tariffs.

In a way the inflation, the collapse of the hryvna, the rapid rise in unemployment and the rise in multiple utilities force the government to direct the large financial resources to the payment of social benefits, subsidies, wage indexation, support the banking system, the army, etc. Last times inflation generally became the one of the largest internal risks to the social welfare.

According to the social researches results, over $61 \%$ Ukrainians admitted the decreasing of their wages by the last half of year 2015. 54\% notes that only inflation is the negative factor influences their life. Over $56 \%$ proved that they started food economy for keeping head above the water (Samayeva, 2015). We admit that the main inflation hit is got by the poor population because their profits majority is connected with social standards - subsistence level and minimum wage. The last point is „frozen” by government but as the result of running inflation, they lost the possibility to provide the minimal life level.

Hryvna devaluation which is caused by the falling of competitiveness ability of Ukrainian economy and transmission to the floating exchange and by the list of other factors increased the speed of inflation development. As the result of this the expenses for import and its finish value increased and the goods with minimal import element also rose in price. Because the majority of consumer goods touched almost all branches of national economy and has generated very negative consumer expectations.

Thanks to the credits of Ministry of Finance, international organizations and strict monetary policy, the currency market is managed to stable. But so new credits increases the current budget expenses for servicing the public debt, and form "debt burden" for future generations which will inevitably cause the tax increasing and limitation of social transfers (Krupa, Nesterovych, 2015).

One more risks group in the sphere of state social policy is connected with reformation performance in social security and retirements. Today situation by the socials risks security in Ukraine at the basis of generally obligatory social security is closely critical which doesn't allow state to limit in a particular improvement.

Superannuation fund of Ukraine for 2015 is approved with the deficit of 19 billion UAH against 17,1 in year 2014. By this the Ukraine's state budget subsidy for the payment of pensions, allowances and increases to pensions for different pension programs reached 61.7 billion USD against 64.6 billion USD in 2014 (Analytical Report, 2015).

Solidary superannuation system in Ukraine got a failure and perspectives in Superannuation Fund balancing according to the today processes in economic, social. Demographic and others spheres which is not foreseen even in middle time perspective. The catastrophic decreasing of GDP which in year 2014 became 6,8\%, in year 2015 (according to calculations in Ministry of Economic Development and trade of Ukraine) - 10\% which extremely negatively influenced to the number of labour places and wages level in our country and essentially made worse the migration processes. As the result of first half of year 2015 by the data in Ministry of Social Policy, situation about the correspondence pensioners with legal working people became near 10 millions who work and pay the taxes for Superannuation fund against 12 millions pensioners (Tamkova, 2015). Deficit of Superannuation fund became 81 millions UAH which must be covered with state budget. As the result when in year 2000 the part of GDP consisted $8 \%$ so in the year 2015 - 16. Such situation makes almost impossible the efficient performance of retirement reform.

Considering the above said it's necessary to admit that powerful negative influence of economic depression caused to the escalation of chronic and institutional crisis for national Ukrainian state and its widening form the economic to social and politic squares. In the reason of critical institutional crisis, it lost the value in purposes of state development and its functions performance. State is understood as the subject which is separated from society and oriented to the interests development of limited personal circle in society (Zhalio, Pokryshka, Berezhnyi, 2011). There are formed the suite conditions for mass protest events.

\section{Conclusions}

The deep crisis of national economic model caused the critical level of system problems in social development which in its turn defined the inability of state social policy. Social economy inability provided the high level of social intensity even on the background of stable increasing in budget extensions for social needs and periodical realization of additional social initiatives. The contrariety between officially declared in policy and consolidated in Constitution of Ukraine and in ratified in international agreements about social orientation and absence of real essential movements in social sphere and by the apparent strengthening of social stratification became the factor of decreasing in reliance to state policy and it agencies, increasing of social irritation.

By the widening of depressive tendencies, it's declined in real purchasing power of incomes and narrowing opportunities for informal (including shadow) income turned contradiction referred to the critical (Zhalilo, 2014). That's why in the conditions of socially-economic and politic state instability, state policy needs the institutional changes which are provided by the non-correspondence in structure and social institutes's quality and requirements of civil system. They are usually accompanied with periodic 
instability when old institutes don't work anymore, and new don't work yet. In such conditions the role of interaction of state and social institutions by the questions of formation, admitting and adaptation of social institutes to the new conditions of social development.

In a way, social policy in modern conditions is universal, necessary and functionally important sphere of social life. Its objective character and realization proportions are defined with the high level of social differentiation and difficultness in social relations in society of modern type which need the non-stop their efforts towards the regulation as a factor of social development. According to this, social policy institute needs the serious modernization especially its functional manifestations that would more clearly direct to the closing for social development of Ukraine to the European standards in the conditions of clear necessity in efficiency increasing of budget tools using in particular with the reason of contrariety to sparseness of state financing and its concentration to the using of the most important programs.

Ukrainian closing to the economic and social standards of developed countries needs the building of the social and justice state, providing of correspond life conditions for socially vulnerable population, efficient system in system of human rights protection. State development should be directed to the creation of correspond level and high life quality in free democratic social state which is the important background in society consolidation and economic development.

In the same time in the conditions of economic development slowing and important crisis risks, the general priority of social policy must be moved to the side of budget expenses rationalization with the increasing of state social responsibility. Government should decrease the social expenses load in a way of private investment encouraging, transmission to the targeted support needy. In conditions of budget means economy, it must be carried out the transmission form the paternalism in social sphere to partnership between state, business and citizens in all aspects of social support.

In general, it may be spoken about success in social policy institute functioning as the regulator social sphere development and as the aspect of institutional state status only in case when the results of such functioning will got the normal state support not only those members of society who really need it, but also be able to achieve a substantial increase in real incomes of all workers and the general life quality of Ukrainian citizens.

\section{References}

The analytical report to the President of Ukraine Annual Message to the Verkhovna Rada of Ukraine "On the internal and external situation of Ukraine in 2015". (2015). - K., 684 p.

Andrushchenko, V.P. (2001). Social Work: A Reader. Book. - K., 396 p.

Voytovych, S.O. (1998). Social institutions of society: family, power, property. - K., 170 p.

State policy in the field of humanities: a textbook / [aut. count., V.A. Skuratovskyi, V.P. Troshchinsky, P.K. Sitnik and others.]. - K., 284 p.

Kryvokon, N.I. (2012). Problems of social work and social policy in Ukraine. Chernihiv, 320 p.

Rice, V.R. (2015). The social policy of Ukraine at the present stage, external challenges and internal threats. Materials of IV International scientific-practical conference "The structural transformation of national economies in the global dimension", 6 November, Mykolaiv, p. 35-38.

Lopushnyak, G.S. (2011). Institutional support for government social policy: theoretical and problematic aspects. Actual problems of public administration, № 2, p. 31-38.

Makarov, O.V. (2015). Social policy in Ukraine: Monograph, Institute of Demography and Social Studies. - K., 244 p. Zhalilo J., Tire D., Belinska Y., Berezhnaya Y. (2011). Post-crisis development of economy of Ukraine: principles of strategy of modernization. - K., p. 72.

Reform of Social Policy in Ukraine: Problems and Prospects: Teach Science. kind. / [Aut. count. , VA Skuratovskyi VP Troshchinsky, PK Sitnik and others.] for the Society. Ed. VA Skurativsky, VP Troshchinsky. - K.; Lviv: NAPA, 2012. - 368 p.

Samayeva, Yu. (2015). Tax on the poor. [Electronic resource]. - Retrieved from: http://gazeta.dt.ua.

Systemic Crisis in Ukraine: preconditions, risks and ways to overcome: analyte. ext. / Zhalilo J.A., Kononenko K.A, Yablonsky V. [et al.] for the Society. Ed. JA spared. - K., NISS, 2014, p. 132

Skurativsky, V.A. (2002). Fundamentals of social policy: teach. guidances. - K., 200 p.

Tamkova, A. (2015). Work will soon no. Express. Number 9, October 15, p. 13.

Shevchuk, P.I. (2003). Social policy. - Lviv, 400 p. 


\section{Лариса ЖУКОВА}

\section{СОЦИАЛЬНАЯ ПОЛИТИКА КАК ФАКТОР ИНСТИТУЦИОНАЛЬНОГО СТАТУСА ГОСУДАРСТВА}

Аннотация. Целью статьи является исследование теоретико-методологических аспектов социальной политики как фактора институционального статуса государства. Методика. Исследование институционального обеспечения государственной социальной политики, которое может рассматриваться как основа для проведения соответствущих реформ, направленных на повышение уровня жизни населения, является достаточно актуальным заданием и в научно-теоретическом, и в практическом аспектах. Научный поиск исследования социальной политики как фактора институционального статуса государства осуществлялся на основе классической, неоклассической и институциональной методологии. На основе классической методологии были определены общие теоретические подходы при помощи инструментов диалектического анализа и синтеза совокупности социальных отношений как исторического явления. При помощи системного, структурно-функционального анализа заданий социальной политики раскрывается её внутренняя природа и пути институционального обеспечения. Институциональный и неоклассический подходы позволили проанализировать специфические инструменты моделирования динамики и результаты института социальной политики в условиях рыночных преобразований. Также в процессе исследования были использованы статьи экономического направления по вопросам анализа социальной политики государства и приведены статистические данные с аналитического доклада ежегодного обращения Президента Украины в Верховную Раду Украины «О внутреннем и внешнем положении Украины в 2015 году». Результаты исследования показали, что в условиях социально-экономической и политической нестабильности, социальная сфера Украины стала заложником общего кризиса в экономике, катастрофического падения уровня жизни населения, роста конфронтации общества и грубых системных ошибок в процессе формирования социальных институций. Всё это нивелирует эффективность мероприятий по улучшению социально-экономического положения населения и препятствует внедрению необходимых реформ. Практическое значение заключается в четком определении приоритетов и направлений социальной политики на государственном уровне, описании основных эффективных способов и форм разрешения социальных проблем граждан, согласовании деятельности различных социальных институций, учёте особенностей социально-экономического развития государства и создании условий для повышения жизненного уровня населения. Украина, стремясь интегрироваться к европейскому пространству и строя собственную стратегию развития, должна чётко осознавать как свои возможности, так и внешние факторы влияния. При выборе возможных альтернатив ведущей идеей социальной политики должны оставаться стремление к социальной справедливости общества и обеспечение устойчивого развития, которое не должно отрицательно сказываться на достижениях будущих поколений. Значение/оригинальность. В процессе исследования доказано, что одним из первоочередных заданий государства должно быть кардинальное изменение вектора социальной политики и проведение безотлагательных экономических и социальных реформ, учитывая, что институт социальной политики требует серьёзной модернизации, особенно в его функциональных проявлениях, которые должны занять позицию курса социального развития государства в направлении европейских стандартов. Стремление Украины к экономическим и социальным стандартам развитых стран нуждается в построении социально справедливого общества, обеспечении достойных условий жизни для социально незащищённых слоёв населения и повышении эффективности работы системы защиты прав человека. В этом направлении правительству необходимо снизить нагрузку социальных расходов на бюджет благодаря привлечению частных инвестиций и осуществить переход на адресную поддержку нуждающихся. В условиях экономии бюджетных средств должен быть осуществлён переход от патернализма в социальной сфере к партнёрству между государством, бизнесом и гражданами во всех аспектах социальной помощи. Результатом успешного функционирования института социальной политики как фактора институционального статуса государства должно быть всеобщее улучшение качества жизни всех граждан Украины. 